natn. Acad Sci. U.S.A., 71, 2900-2904; 1974) now repont that they can be isolated by their ability to bind preferentially to actinomycin $C_{1}$ which causes them to form a low density band. The band isolated in this way hybridises well with a preparation that contains the messengers for four histones (mRNA activity for histone $F_{1}$ has not yet been demonstrated); since each of the four histone messengers shows a virtually identical reaction with the fractions of DNA separated on the CsC1-actinomycin gradient, it is likely that the different histone genes are intermingled rather than clustered in four individual groups.

Comparison of $\mathrm{G}+\mathrm{C}$ content of histone DNA and RNA, and the results of shearing and of melting histone DNA all suggest that the histone gene cluster also contains other sequences that are poorer in $\mathbf{G}+\mathrm{C}$ content. The release of the histone-coding from the other sequences only by shearing suggests that both componenits are integral parts of the gene cluster. The melting curve of renatured DNA from the preparation implies the presence of some heterogeneity in sequence, probably in the sequences which do not code for histones. Whether the component poor in $\mathrm{G}+\mathrm{C}$ represents a nontranscribed spacer region analogous to that of the rDNA gene cluster is not of course revealed by present data but this is one of the functions that can be imagined for it.

\section{Two by two}

from $D$. $H$. Jennings

IT is rare these days to attend a conference covering the whole spectrum of biology. But the Society for Experimental Biology mounted such a conference-on symbiosis-at Bristol on September 2-6. By retaining the original de Bary definition, namely that symbiosis is the association of two different organisms, it was possible to have all shades of interest from molecular to whole organism biology represented. Thus, ecologists, though not contributing directly, could find much to interest them. Indeed, two contributions were particularly seminal for ecological studies. Fricke (Max-PlanckInstitut, Seeiweesen) indicated how behavioural studies of organisms in the Red Sea can provide an understanding of animal interactions in nature thus adding flesh to the bare bones of numerical population studies. Cox (Kings College, London) discussing his work on intraerythrocytic parasites, pointed out that population biologists cannot continue to think about particular species without considering their parasites. He showed how susceptibility to various virus diseases can be dramatically modified by the presence of parasites.

There was much emphasis on how the invading symbiont avoids attack by its potential host. Terry (Brunel University) and Smithers (National Institute for Medical Research, Mill Hill) presented their elegant studies on the evasion of the immune response by Schistosoma which can survive by its ability to acquire host molecules. Muscatine (University of California, Los Angeles) provided data indicating the recognition by Hydra of the appropriate Chlorella cells takes place after engulfment at the stage when the algal cells move to the base of the digestive cells. Studies on symbiosis in Paramecium are now also beginning to yield relevant information with respect to bacteria (Preer, University of Indiana, Bloomington) and Chlorella (Karakashian, Max-Planck - Institut, Wilhelmshaven).

In spite of the decision to use the de Bary definition, there was much discussion of what is meant by the term 'symbiosis'. Mortimer Starr (University of California, Davis) produced a new classificatory scheme which has the virtue of both clarifying thinking about the phenomenon and indicating where further experimental work is required-to decide, for example, whether a symbiotic association is mutualistic or obligately parasitic. In this respect, Smith (University of Bristol) put those interested in lichens further in his debt by his careful analysis of the present data in the field which indicate that there is no detectable benefit to the algal partner. Also Coffey (Trinity College, Dublin) presented further information about the rust fungi, once thought to be the classic example of obligate pathogens in plants but which can now be grown in culture.

Many problems are emerging for the biochemists, particularly on how a symbiont affects the physiology of the host which it has invaded. Biochemists should be impressed by Aplysia which does a far better job than they of isolating chloroplasts. There is no doubt, as shown by Trench (Yale University), that these chloroplasts are fully functional, though the relationship between these organelles and the animal cytoplasm in which they reside is not the same as that which exists in the intact cell from which the chloroplasts are extracted.

But biochemists and molecular biologists have other reasons for being interested in symbiosis. Chloroplast symbiosis is, in a number of ways, the living expression of how eukaryotic organelles are believed to have arisen, namely by successful invasion of a primitive glycolytic prokaryote by oxygen utilising (to give mitochondria) and photosynthesising (to give chloroplasts) prokaryotes. Though the theory has a respectable age, Lynn Margulis (University of Boston) has done the most recently to bring it up to date. In a debate on the theory she propounded her views with infectious enthusiasm. But though most of the audience were believers, Raff (University of Indiana, Bloomington) in a careful comparison of bacteria and mitochondria showed that their faith may be blind.

\section{Five hundred million years ago in Wales}

\section{from I. Strachan}

Aвоuт half of those attending the symposium organised by the Palaeontological Association of London on the Ordovician System (September 17-20) had spent the previous week touring Wales looking at the classic geological sites of Arenig, Llandeilo, Caradoc and Bala.

Much of the material presented at the meeting in Birmingham was factual and included new information as well as regional summaries, but there was also a considerable questioning of current dogmas. F. J. Fitch (Birkbeck College, London) and others speaking on Ordovician geochronology pointed out the possible sources of error inherent in radio-isotopic dating, particularly in Lower Palaeozoic rocks, and stressed the need for the use of standard reference scales (such as that produced by the Geological Society of London in 1964) so that data from different sources could be accurately compared. They concluded that a length of $65 \mathrm{Myr}$ (between 510 and $445 \mathrm{Myr}$ ago) was reasonable for the Ordovician, compared with $70 \mathrm{Myr}$ for the preceding Cambrian and 40 Myr for the succeeding Silurian.

Given this broad time span, it was not surprising that the details of the regional pictures presented by later speakers should show some differences. The biostratigraphical problems were analysed in various groups of fossils. W. B. N. Berry (University of California) related his graptolite faunas to warm and cool water masses using a palaeogeographical reconstruction with the land all on one hemisphere. M. Lindström (University of Marburg) felt that the conodont faunas agreed in provincialism with the graptolites but C. R. C. Paul (University of Liverpool) found distinct North American, Baltic and Mediterranean cystid faunas only up to the lower part of the Caradocian, after which time provincial boundaries became fuzzy. This he related to closing up of ocean basins 